\section{THEMISTAKE}

IN THE
IMPLEMENTATION OF

MANAGEMENT

IN INDONESIA

The background of writing this book is due to the low understanding and knowledge of the company managers in managing the risks that will be faced. The company's performance that continues to grow and develop is a dream and hope to be realized from time to time. However, the fact is the company's performance is not only seen from how much the number of profits each year, but also how much the company can maintain and manage every risk faced. Companies with large assets and a large number of branch offices cannot guarantee that their performance will continue to increase, evidence has been found that companies that have complete resources and with long experience but have very poor performance.

This book was created to be able to provide a real example of the mistakes in implementing risk management by companies in Indonesia. In Chapter 1, an example of the Rabobank case, which has assets of 13.82 trillion rupiahs (2018), has been established since 1990 and has had 33 branches throughout Indonesia, but gradually in June 2020 declared it stopped operating in Indonesia. What happened, the author will review in this first chapter. Followed by chapter 2, an example of the case of the placement of commitments made by Garuda Indonesia with Mahata in the 2018 financial statements, in the other income section that caused a polemic, where Garuda revenue in 2017 of US $\$ 213.39$ million turned very significantly into the positive income of US $\$ 5.02$ million, this drastic change will be what the author tries to explain in this second chapter.

The next chapter 3, describes Bank Tabungan Negara which was established in 1934 and has total assets of 312 trillion rupiahs (2019) with a total of 78 branch offices. However, the company's profit growth which should continue to grow and develop each year, actually experienced a very significant decrease in 2019 to 209 billion rupiahs, down $90 \%$ from the previous 2.8 trillion rupiahs in 2018 , what happened ? the author will try to explain it in chapter three. Finally, in chapter 4 , it is explained about the financial problems faced by Jiwasraya, which has stood for 160 years with assets in 2017 amounting to 45 trillion rupiahs, suddenly suffered a loss of 13 trillion rupiahs with debts of 49 trillion rupiahs in 2019, what happened? the author will explain it in chapter four of this book.

In chapter five, the author will give an example of a company that has successfully implemented risk management in a good and measurable manner, so that the company can avoid waste and finally be able to optimize operating income properly. Which can reverse the company's loss position, becomes a significant profit.

Finally, hopefully, the cases that occur in several companies that are used as examples in this book can provide valuable knowledge, so they will not be repeated in the future.
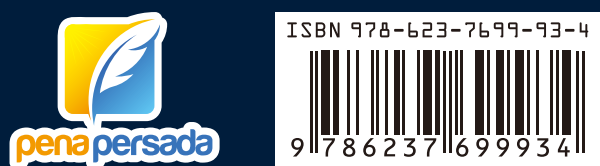

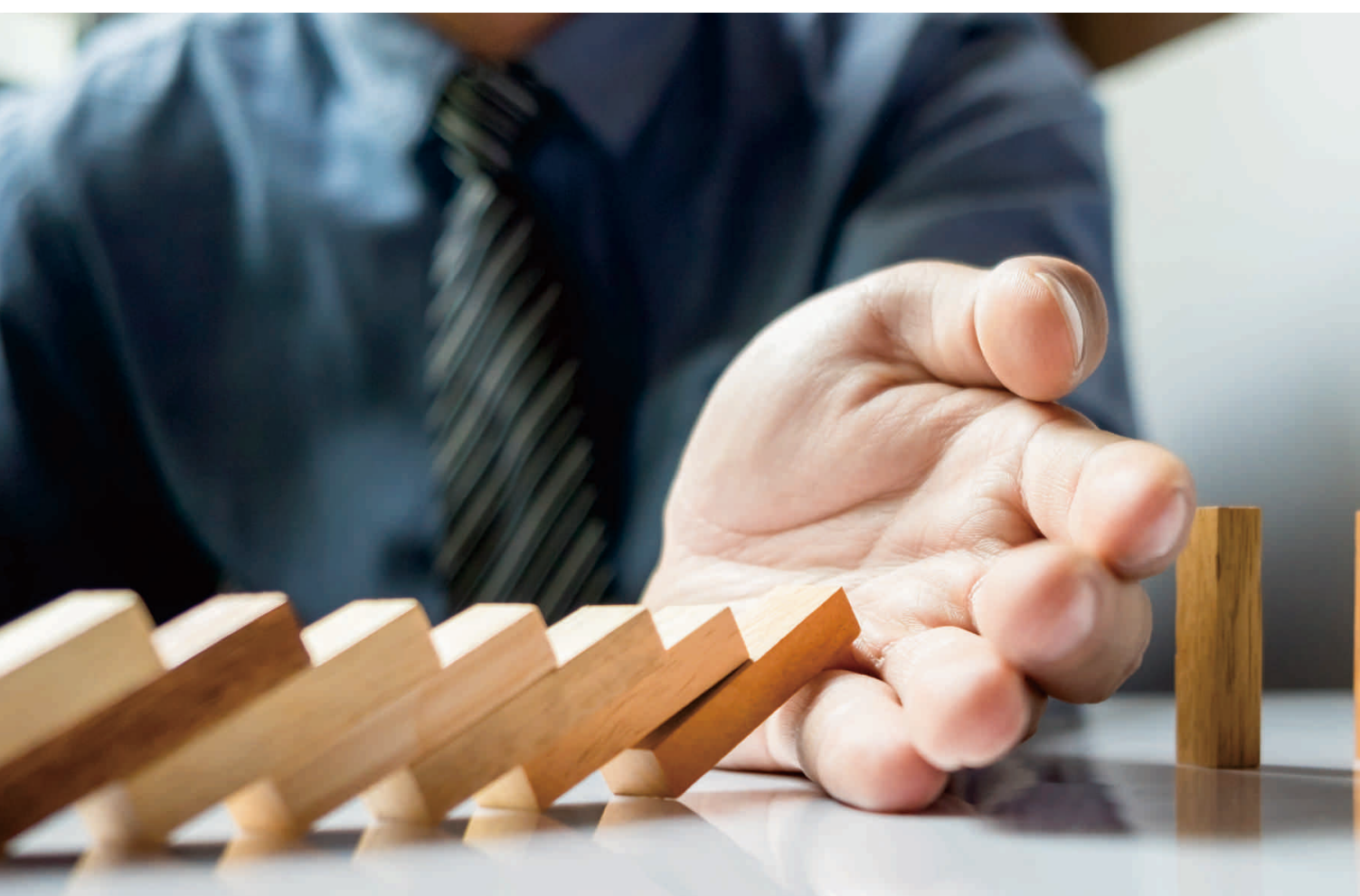

Girang Permata Gusti

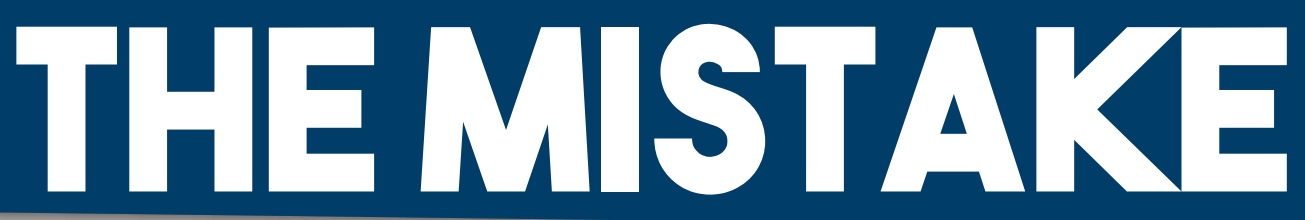

IN THE IMPLEMENTATION OF MANAGEMENT IN INDONESIA

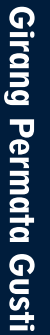

(CASE STUDY ON RABOBANK, GARUDA INDONESIA, BTN, AND JIWASRAYA)

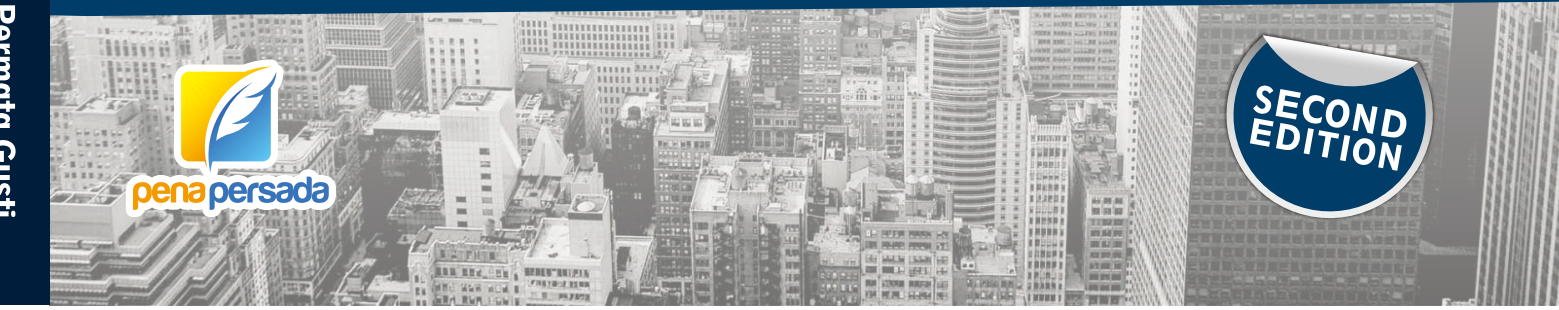




\section{THE MISTAKE IN THE IMPLEMENTATION OF RISK MANAGEMENT IN INDONESIA (CASE STUDY ON RABOBANK, GARUDA INDONESIA, BTN AND JIWASRAYA)}

(SECOND EDITION)

Girang Permata Gusti

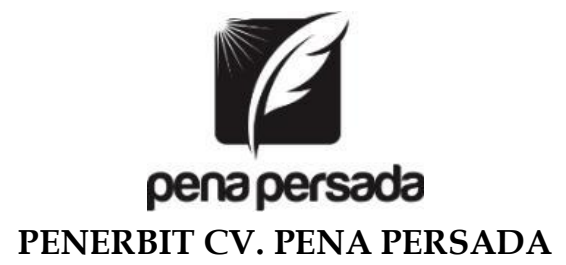




\title{
THE MISTAKE IN THE IMPLEMENTATION OF RISK \\ MANAGEMENT IN INDONESIA \\ (CASE STUDY ON RABOBANK, GARUDA INDONESIA, BTN AND JIWASRAYA)
}

(SECOND EDITION)

\author{
Penulis : \\ Girang Permata Gusti \\ ISBN : 978-623-7699-93-4 \\ Design Cover : \\ Retnani Nur Briliant \\ Layout : \\ Nisa Falahia \\ Penerbit CV. Pena Persada \\ Redaksi : \\ Jawa Tengah \\ Email : penerbit.penapersada@gmail.com \\ Website : penapersada.com \\ Phone : (0281) 7771388
}

Jl. Gerilya No. 292 Purwokerto Selatan, Kab. Banyumas

Anggota IKAPI

All right reserved

Cetakan pertama : 2020

Hak cipta dilindungi oleh undang-undang. Dilarang memperbanyak karya tulis ini dalam bentuk apapun tanpa ijin penerbit. 


\section{INTRODUCTION}

(First Edition)

The writing of this book is motivated by the author's curiosity about the performance of a long-standing company, with a large number of assets and with a large number of branch offices and even received full support from the government of the Republic of Indonesia, but instead showed a disappointing performance. All the resources that are owned and with long-term experience can not be a guarantee that the company will have a good financial performance and can be accounted for in every financial statement preparation.

History will continue to experience the same repetition and events in the future. It takes real effort if you want to change the situation for the better than before. Learning from the experiences of companies that are wrong in managing corporate risk management, the community and potential investors should have adequate knowledge when deciding to buy investment products. In order not to become a victim of the promotion method with the scheme gives a promise of great profits, but the result is a loss. The public must be aware and critical of the various offers made by the company's marketing, so as not to get caught up in investment schemes that provide big returns. Communities must invest their time in advance to be well informed so that they have sufficient knowledge when deciding to invest.

This book provides an example of a case where the application of risk management is wrong, so the company is experiencing losses due to incorrect decisions. It is hoped that we can learn from the mistakes they have made. Thanks.

Girang Permata Gusti 


\section{INTRODUCTION}

\section{(Second Edition)}

For this second edition, I provide improvements in chapter two so that it is more easily understood by readers. Improvements include citing bibliography, writing unclear sentences, and affirming from the author the conclusions obtained from observations of financial activities undertaken by Garuda with Mahata.

Next is the improvement in chapter three, where I provide an additional model to make it easier for readers to understand the credit assessment process so that they can avoid bad loans that harm financial activities and worsen bank performance.

Finally, in this second edition, I add chapter five, which contains examples of cases of Indosat companies that have successfully implemented Risk Management well.

Hopefully, this book can provide benefits for improving company performance, especially in terms of applying risk management.

Girang Permata Gusti 


\section{TABLE OF CONTENTS}

INTRODUCTION (First Edition).................................................... iii

INTRODUCTION (Second Edition) ............................................. iv

TABLE OF CONTENTS...........................................................

CHAPTER I PT. BANK RABOBANK INTRNATIONAL

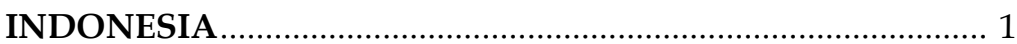

A. RISK MANAGEMENT ERROR ………........................... 1

B. OPERATIONAL RISK CASE ............................................. 2

C. BANK'S OPERATIONAL PROCESSES ............................... 7

D. ANALYZING CUSTOMER TARGETS ……........................ 12

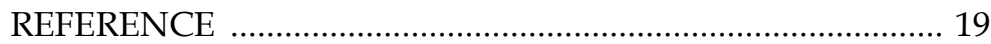

CHAPTER II PT. GARUDA INDONESIA (PERSERO) TBK .... 22

A. "WINDOW DRESSING STRATEGY ................................... 22

B. ACCRUAL BASIS AND CASH BASIS................................. 23

C. FINANCIAL PERFORMANCE ........................................ 27

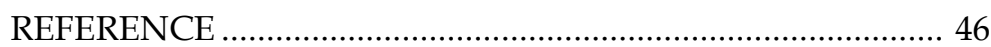

CHAPTER III PT. BANK TABUNGAN NEGARA (PERSERO)

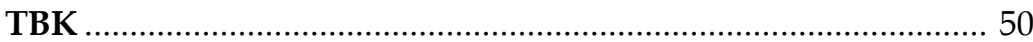

A. COMPANY BUSINESS ACTIVITIES …………................. 50

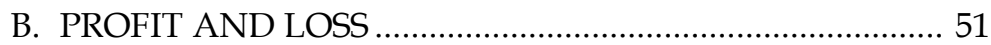

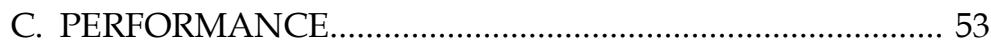

D. RISK MANAGEMENT CYCLE ........................................ 60

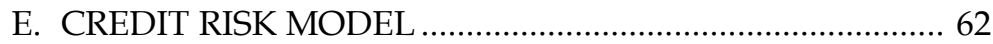

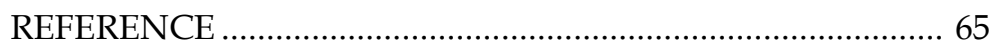

CHAPTER IV PT. ASURANSI JIWASRAYA (PERSERO)......... 67

A. ERRORS IN FINANCIAL MANAGEMENT ...................... 67

B. FRAUDULENT FINACIAL STATEMENTS ......................... 68

C. INSURANCE COMPANY BUSINESS MODEL ................... 70

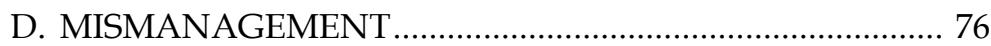

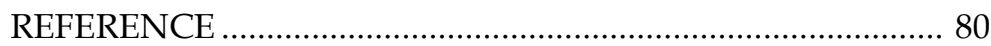

CHAPTER V PT. INDOSAT TBK ……………........................ 84

A. TRIAL OF VARIOUS BUSINESS STRATEGIES ................ 84

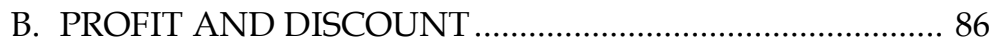

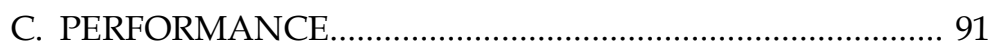

D. DATA (INTERNET PACKAGE) ............................................ 91

E. DISCOUNT AND CASH BACK ........................................ 93 


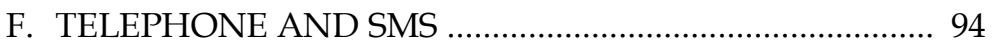

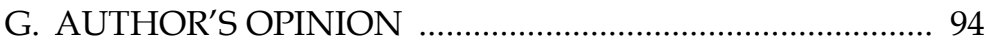

H. INDOSAT BUSINESS STRATEGY MODEL ….................... 98

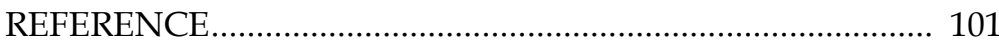




\section{CHAPTER I \\ PT. BANK RABOBANK INTERNATIONAL INDONESIA}

\section{A. RISK MANAGEMENT ERROR}

Risk management error is becoming a disaster for companies that are unresponsive to environmental changes. Adjustments to changes in the dynamics of consumers ' wishes and changes in public income sources must be predictable by the company well. Companies that impose their desire to focus only on one particular field will have difficulties, considering that each region has its diverse characteristics and supply resources. The same explanation was conveyed by (Apostolik, Donohue, and Went (2009); Zedda (2017)) which states that operational risk is present in almost all bank transactions and activities are the main concern of bank supervisors, regulators, and bank management. Failing to understand operational risk increases the likelihood that the risk will not be recognized and uncontrolled, thus potentially inflicting harm to the bank. There have been many studies relating to bank risk management and errors in the operation of the company, causing risk management activities to fail (Bouheni, Ammi, \& Levy, 2016; Ghosh, 2012a; Girling, 2013; Lukason \& Hoffman, 2014; Zedda, 2017).

Stop operating PT. Bank Rabobank Internasional Indonesia (RII), which has total assets of 13.82 trillion rupiahs in 2018 and has been established since 1990 and has as many as 33 branch offices throughout Indonesia is a question. What happened? Is it for reasons that it is not in line with the Indonesian market conditions that are more towards the retail business than to wholesale banking and the changing focus of companies that only choose in the field of food and agriculture is the main reason for the company's closing? Are the debt of 12.71 trillion rupiahs in 2018 and the ratio of loans to customer deposits of $139.66 \%$ in 2018 are also one of the causes?. A large 
amount of the ratio of loans to customer deposits which has exceeded the safe limit is implicitly following research conducted by Zedda (2017) Which states that each economic activity implicitly encompasses risk, as the economic framework always includes uncertainty. But bank activity is centered at risk because its core business is in lending money.

Logically, companies that have high profitability will continue to be maintained and developed to be better, on the contrary companies with very low profitability and even continue to lose will stop their operational activities because it is certainly considered unprofitable. Whatever the reason, the company which has been established for 29 years and is a merged bank between Rabobank, Hagabank and Bank Hagakita should be able to adapt very well and be responsive to any changes, but which have happened in the last 10 years (2009 - 2018) the company's operations reached 975.62 billion rupiahs. There is a very interesting sentence to be reviewed 'There are no rich farmers here' (Akbar, 2019) delivered by Joseph F.P. Luhukay as the newly appointed President Director on January 16, 2018 (after passing the feasibility and propriety by the OJK) but 16 months after his leadership the company with a vision of banking for food actually stated that it stopped operating activities gradually starting April 2019, to be officially closed on the month June 2020.

\section{B. OPERATIONAL RISK CASE}

Banking risk is the probability of an actual return on an investment will be lower than the expected return. Financial risk divided into many categories: capital risk, state risk, default risk, shipping risk, exchange rate risk, interest rate risk, liquidity risk, system risks, political risk, market risk, credit risk, risk of refinancing, risk of reinvestment, risk of settlement, state risk, Risk of underwriting, etc. (Bouheni et al., 2016). According to Lesmana and Surjanto (2004, pp. 183-184) signs that can be seen against a company that has difficulty in its business. First, sales or revenues have experienced a significant 
decline. Second, a decrease in profits and cash flow from operations. Third, a decrease in total assets. Fourth, stock prices declined significantly. Fifth, the possibility of failure in industry, or an industry with high risk. Sixth, young companies that generally experience difficulties in the early years of their operations, so that if not supported by a strong source of capital, there will be serious financial difficulties and end in bankruptcy. Seventh, significant deductions in dividends.

The bank's operational risk continues to evolve, along with the progress and complexity of the environment and society. The definition of operational risk has grown rapidly over the last few years. First, it is usually defined as any uninsurmountable risk faced by a Bank. However, further analysis has refined the definition. Operational risk has been determined by the Basel Committee on Banking Supervision Risk of inadequate internal loss or failure to Processes, people and systems or from external events. This definition Including legal risk, but excludes strategic and reputation risks. These Definitions are based on underlying causes of operational risk. He sought to identify why losses occur and at the widest level include parsing four Causes: People, processes, systems, and external factors (Huertas, 2016). According to Siahaan (2009, p. 24) the potential for financial losses due to triggers from outside the organization, in the form of four exogenous factors that are outside the organization's ability to control it. The first is the interest rate, which is the risk of loss due to changes in interest rates. The second is a foreign exchange, namely the risk of loss due to changes in foreign exchange rates. The third is credit, that is a risk because there is a party who is injured in the promise so that it cannot fulfill its obligation to repay the loan on time. Fourth is liquidity and cash flow, and this risk is triggered by the inability of internal organizations to provide cash, this risk is caused by internal factors or called endogenous factors. 
The risk of business operational activity and the controlling risk itself requires adequate ability to run it. It is not easy to manage risk, considering that the customer funds deposited must be able to be accountable by the bank. Banks are required to provide low risk analysis, but are able to provide substantial benefits for banks and customers . Simply, banks are faced by two big risk categories (Ghosh, 2012b), namely business risk and controlling risk. First, business risk is the risk inherent in business and arising from such incidents of some expected or unexpected events in the economy or financial markets, causing erosion in asset value and consequently a decrease in the intrinsic value of the bank. Secondly, the risk of control refers to inadequacy or failure of control that is intended to examine the intensity or volume of business risks or prevent the spread of operational risk. According to Siahaan (2009, pp. 25-26), the risks that disrupt the company's operations consist of the company's internal and external risks. Internal organizational risk is triggered by weak accounting controls that cause errors or omissions in the financial accounting process. The external risk of an organization is influenced by three components - first, regulations in the form of new regulations that cause losses. Second, cultural changes from the outside can cause harm. Third, changes in the composition of the board of directors or supervisors from outside the organization can cause losses. Other operational risk triggers, namely the failure of the recruitment process that causes counter-productive or inefficiency and disruption of the organization's raw material entry channels.

Banks should be able to manage risk well; the prudence in making strategic decisions is key in minimizing errors. Errors due to confusion in the determination of strategic policy of the company causing losses should immediately be promptly handled properly, otherwise will cause the bankruptcy of the company. A brief explanation of the type of risk conveyed by Fahmi (2010, p. 5) who stated that there are two types of risks, 
namely pure risk and risk of speculation. Pure risk can be grouped into three types. That is the risk of physical assets such as fire-earthquakes, employee risks such as workplace accidents, and legal risks that are not following the plan. Meanwhile, the risk of speculation is grouped into four types. That is the market risk that experiences a decline in stock prices, credit risk that fails to fulfill its obligations to the company, low liquidity risk, so it is unable to meet cash needs, and finally, operational risks that do not run smoothly.

Bank institutions actually cannot avoid risks, but risks can be minimized by proper management standards. Bank risks explained at a glance by researchers Fahmi (2010, pp. 100-101) Who argue that banking is an institution that is the most vulnerable or close to risk, especially the risk associated with money, banking position as mediation, namely the party that connects parties who have excess and lack of money has always maintained good relations with both parties. Banking decisions must always be moderate in that they consider the desires of both parties, so that customer funds (deposits) and customer loan flows (credit) must always be balanced. Banking risk is the risk experienced by the banking business sector as a form of various decisions made in various fields such as credit distribution decisions, issuance of credit cards, foreign exchange, collections and various other forms of financial decisions that cause losses to these banks, and the losses are in financial form.

Credit risk, market risk, operational risk and liquidity risk are four important risks that the bank must handle properly and correctly, in accordance with the risk handling process. Simple and understandable explanation conveyed by Fahmi (2010, p. 104), who stated that, there are four banking risks defined or required by Bank Indonesia to be managed. First, credit risk caused by the inability of debtors to fulfill their obligations. Second, market risk (such as exchange rates and interest rates) caused by market movements from normal conditions to abnormal conditions that cause losses. Third, 
operational risks arising from internal bank factors. Fourth, liquidity risk arises because of the inability to fulfill short-term obligations. Of the four risks, the results of the research state that the biggest risk is a credit risk.

The company's bankruptcy situation is a situation that occurs due to mistakes in financial management, resulting in a higher company burden and a lower company's profitability. A brief explanation is conveyed by Darsono and Ashari (2005, p. 101), bankruptcy is a situation where the company's liabilities are higher than the value of its assets, whereas financial difficulties can be interpreted as the inability of the company to pay its obligations at maturity which causes the company's bankruptcy. Other explanations relating to the impact of the financial ratios on the company's performance, expressed by Azis and Hartono (2017) on the effect of good corporate governance, capital structure, and leverage on the company's financial performance. The sample of this research is 28 mining companies listed on the Indonesia Stock Exchange from 2011 to 2015. This study draws conclusions which include the ratio of debt ratios to company assets negatively influencing company performance.

The greater the reserve of funds to overcome losses, the more it shows that the company is in a weak position because of course, the funds used will affect the cash flow of the company. A simple explanation is conveyed by Febriati (2013) who argue that reserves for Impairment Losses are reserves that must be formed by a bank if there is objective evidence of impairment of financial assets or groups of financial assets as a result of one or more events that occur after the initial recognition of the asset (adverse event) and impact on estimated future cash flows. The amount of the allowance for losses is measured as the difference between the carrying amount of the financial asset and the present value of the estimated future cash flows discounted using the financial asset's original effective interest rate. 


\section{BANK'S OPERATIONAL PROCESSES}

Figure 1. Bank's Operational Processes

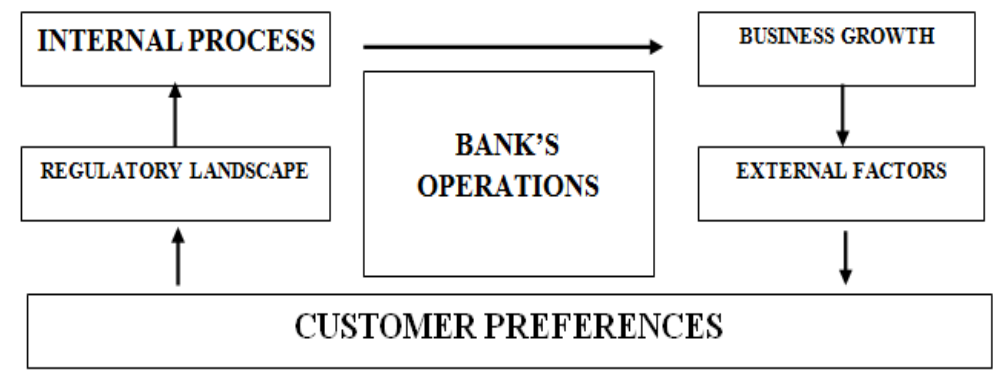

Source: Vysya and Gill (2018).

Circulation and cycle of the bank's operational (risk) system is shown in figure one, in figure one explanation starts from the bank's internal processes related to complex internal processes, communication constraints for cross-functional teams, problematic information technology and conflicts of interest between employees, which in turn causing the loan to be approved without checking collateral. Then the next stage about business growth, this stage is related to the process of increasing business growth, people and systems that are under pressure, errors in sales of products and services, complex products, which in turn lead to meeting sales targets and opening new accounts achieved without knowing consumers. The next stage is an external factor consisting of errors in economic predictions, financial instability, and malfunctions from ATMs. Furthermore, the consumer preference stage is the high expectations of consumers who are incompatible with the products and services available, differences in products and services offered by public financial sources, differences in environmental models and types of consumer preferences with the products and services offered. Finally, there are stages of the regulatory landscape, namely very strict regulations, increased licensing requirements from government regulations, licensing requirements that are difficult to achieve, and complicated regulations. 
The author will try to connect with the process of operational activities at PT. Bank Rabobank Internasional Indonesia, where the author argues that the biggest mistake in risk management activities is the mistake of adjusting to consumer preferences, where Indonesian consumers are more dominated by retail business than corporate business, then exacerbated by the change in focus of companies that only choose consumers who are engaged in the food and agriculture sector has made narrower and smaller consumer selection segmentations. It is undeniable that following the focus of the strategy of the group of companies is mandatory to do, but keep in mind that each region has different characteristics of consumers, the focus of the strategy to increase corporate profits should be adjusted to the needs and models of consumers in each region.

Furthermore, the author will try to connect with the business growth of PT. Rabobank Internasional Indonesia, for the past ten years, as presented in table one.

\section{Table 1. Financial Statements of PT. Rabobank Indonesia Bank (in millions of rupiahs)}

\begin{tabular}{cccccccc}
\hline & $\begin{array}{c}\text { Total } \\
\text { Assets }\end{array}$ & $\begin{array}{c}\text { Total } \\
\text { Debt }\end{array}$ & $\begin{array}{c}\text { Opera- } \\
\text { ting } \\
\text { Income }\end{array}$ & $\begin{array}{c}\text { Net } \\
\text { Profit }\end{array}$ & LDR & $\begin{array}{c}\text { Net Cash } \\
\text { (Operation) }\end{array}$ & $\begin{array}{l}\text { Emplo } \\
\text { yees }\end{array}$ \\
\hline $\mathbf{2 0 0 9}$ & $11,346,456$ & $10,180,930$ & 197,775 & 116,286 & $114.78 \%$ & $1,670,694$ & 1,708 \\
$\mathbf{2 0 1 0}$ & $12,846,214$ & $11,614,277$ & 114,314 & 98,801 & $113.05 \%$ & $1,192,303$ & 1,647 \\
$\mathbf{2 0 1 1}$ & $13,327,844$ & $12,045,283$ & 55,004 & 41,582 & $97.16 \%$ & 509,548 & 1,546 \\
$\mathbf{2 0 1 2}$ & $13,849,378$ & $12,547,841$ & 56,358 & 20,276 & 104.77 & $(352,817)$ & 1,564 \\
$\mathbf{2 0 1 3}$ & $13,543,875$ & $12,156,148$ & 11,680 & 38,166 & 107.7 & $(46,316)$ & 1,327 \\
$\mathbf{2 0 1 4}$ & $16,075,581$ & $14,661,808$ & 61,809 & 23,133 & $88.51 \%$ & $1,385,364$ & 1,398 \\
$\mathbf{2 0 1 5}$ & $15,292,213$ & $13,773,446$ & $(81,0516)$ & $(717,031)$ & $103.14 \%$ & $(966,200)$ & 807 \\
$\mathbf{2 0 1 6}$ & $13,085,847$ & $11,298,490$ & 54,287 & 260,407 & $92.26 \%$ & $(190,421)$ & 770 \\
$\mathbf{2 0 1 7}$ & $11,888,583$ & $10,086,116$ & 19,697 & 1,505 & $104.65 \%$ & $(76,019)$ & 722 \\
$\mathbf{2 0 1 8}$ & $13,816,214$ & $12,713,598$ & $(73,6025)$ & $(704,239)$ & $139.96 \%$ & $(3,715,40)$ & 612 \\
\hline & & & & & & &
\end{tabular}

Source: Rabobank Indonesia's Annual Financial Report 
In the 2009 financial statements, the largest income that led to the increase in the company's net profit came from interest income which rose by $15.2 \%$ to 1.17 trillion rupiahs and an increase in operating income by $82.15 \%$ to 197.77 billion rupiahs, both of which contributed to the company net amounting to $91.50 \%$ to 116.28 billion rupiahs. Continued in the 2010 financial report, Rabobank stated that in line with the global strategy (Rabobank Group), the bank only focused on the Food and Agribusiness sector, where the bank decided not to continue banking relations with customers not from this sector. This affected the decline in net interest income by $14.2 \%$ to 547.9 billion rupiahs, which caused the company's net profit to decline by $15.04 \%$ to 98.8 billion rupiahs. Continued in the 2011 financial report, Rabobank again continued to focus on only serving customers from the food and agribusiness sectors which caused a decrease in the company's operating cash flow of 57.26 percent to 509.5 billion rupiahs, which of course affected the company's net profit by $55.88 \%$ to 41.58 billion rupiahs

For Rabobank's financial statements in 2012 there was an increase in the credit ratio to customer savings, from the previous $97.16 \%$ up to $104.7 \%$ and also the increase in the NonPerforming Loans (NPL) to $1.14 \%$, the two components causing an increase in the value of loss financial assets rose by $75.4 \%$ to 131.7 billion rupiahs. This caused the company's net profit to decline to $51.24 \%$ to 20.27 billion rupiahs. Then, in the 2013 financial statements, there was a decrease in the company's net profit by $2.92 \%$ to 38.16 billion rupiahs, this was due to a decrease in the company's net interest income by $3.81 \%$ to 589 billion rupiahs and a decrease in the company's operating profit by $85.54 \%$ to only 11.68 billion rupiahs. Furthermore, in the 2014 financial report, there was a decrease in net profit of $39.4 \%$ to 23.1 billion rupiahs, this was due to a decrease in the amount of other operational income by $2.85 \%$ to 586.87 billion rupiahs and a non-operating net burden of $345.66 \%$ or a loss of 20.05 billion rupiahs. 
Continuing on the 2015 financial report, Rabobank Indonesia received an injection of aid funds from Rabobank Group of US \$ 35 million in May 2015 and again in December 2015 received capital assistance of US \$ 26 million, management's efforts to enlarge liquid access and increase the company's cash flow proven to be able to provide a major influence on the performance of the company, wherein the 2016 financial statements Rabobank Indonesia recorded a net profit of 260.4 billion rupiahs from the previous year's loss of 717 billion rupiahs. However, this achievement was also followed by a reduction in the value of company assets from the previous year amounting to IDR 15.3 trillion, in 2016, it dropped to IDR 13 trillion.

In the 2016 financial statements, the largest decline occurred in the number of customer savings from 2015 for 10.2 trillion rupiahs, down to 7.96 trillion rupiahs, this caused the company's interest income to also decrease from the previous 1.26 trillion rupiahs to 895.7 billion rupiahs, this has a very big impact from the decline in the company's net income which is very significant to only 1.5 billion rupiahs from the previous record profits of 260.4 billion rupiahs. Continued with the 2017 financial report, there was a very drastic decline in the company's net profit from the previous amount of 260.4 billion rupiahs to only 1.5 billion rupiahs, this was due to the decrease in the company's non-operating income of only 14.5 billion rupiahs from 264.6 billion rupiahs and the company's operating profit which only amounted to 19.7 billion rupiahs from the previous amount of 54.3 billion rupiahs.

In the phase where the focus of service follows the strategy of Rabobank Global as the controlling shareholder (with the vision of Banking for Food), which only focuses on the Food and Agribusiness sector customers by not serving customers in other sectors, (in the author's opinion) starting from this phase gradually installments have hampered and weakened financial performance significantly, resulting in a reduction in the number of customer savings, a reduction in the 
number of employees, an increase in the company's operational expenses which certainly affects the company's cash flow operational activities, which in turn have an impact on the company's net profit the point where 2015 recorded the biggest loss in the last 10 years (2009-2018) amounted to 717 billion rupiahs and posted a loss again in 2018 amounting to 704 billion rupiahs. This continuous loss has caused Rabobank Indonesia to no longer be able to continue its operational activities in 33 branch offices throughout Indonesia with 12 thousand customers.

Until finally, a very important note and will be the history of the end of this company is in the 2018 financial report, namely the termination of Bank operational activities that have been established in Indonesia for 29 years, by voluntary liquidation (itself) which will be a key assumption as the basis for the preparation of bank financial statements in the following period. As well as the final preparation of the closing process of Rabobank in June 2020. To fulfill all of its obligations at maturity, Rabobank Group as the controlling shareholder again disbursed its loan funds on December 5, 2018, for US \$ 50 million as a form of the long-term loan agreement, then May 20, 2019, amounting to US \$ 570 million as a form of a short-term and last-term loan agreement on May 23, 2019, amounting to US \$ 50 million as a form of security to facilitate Rabobank's liquidity, considering the ratio of credit funds to customer deposits (LDR) of $139.96 \%$, which logically indicates that (if Rabobank doesn't get a loan) the Bank does not have sufficient funds to help customers (as many as 12 thousand) transfer all of their funds to other banks, with the amount of customer savings in 2018 as much as 7.85 trillion rupiahs. Of course, we must appreciate the earnest efforts of Rabobank group who are very responsible for each of its obligations, with the support of $100 \%$ from the controlling shareholders making the Bank's operational cessation process expected to run according to the existing plan besides, if comparing with Rabobank Group's net income in 2018 amounting to 3 billion euros with assets of 590 
billion euros, indicating that Rabobank Group is very capable of fulfilling each of its obligations.

The company's financial discussion of PT. Bank Rabobank International Indonesia demonstrates that the company over the last ten years has undergone financial distress, causing it in the last year (2018) financial reporting self-proclaimed to cease operation in Indonesia. This demonstrates the tremendous impact of financial distress that gradually causes the company to bear ever greater losses every year. These results are in line with the research done by Ufo (2015), stating the financial condition distress in the form of circumstances in which the cash flow of the company's operations is insufficient or even less to close the current debt payments and companies are forced to take corrective action. The financial distress in the company greatly affects the company's performance, and results cause the company to repay debt. It can be said that the company's ability to pay the timely debt is negative, and the early stages of financial difficulties can be a reduction in revenues. This, in turn, leads to profitability and the liquidity ratio of the company decreases due to high company debt.

\section{ANALYZING CUSTOMER TARGETS}

In the 2018 financial report. With a total debt of 12.7 trillion rupiahs and total assets of only 13.8 trillion rupiahs, the credit to customer savings ratio is $139.96 \%$ with a total net loss of 704 billion rupiahs. Of course, we can very easily imagine what will happen to this company going forward. No company will be able to survive if the business strategy run by the controlling shareholders is not in line with the needs and circumstances in which the company operates.

The importance of being able to keep abreast of developments and changes in the regions in which the bank operates is crucial, given the changing dynamics of prospective customers' financial resources must be following the target consumers to be achieved in the region. The mistake in 
analyzing customer targets that are not by the characteristics of the region will cause an increase in the company's operational burden because the target customers are not appropriate, which in turn the risk of bankruptcy can not be avoided. Illustration of the explanation of the relationship between time and risk is shown in figure two (Rasheed, Yaqub, Wang, Memon, \& Lucena, 2018).

\section{Figure 2. The Relationship Between Time and Risk}

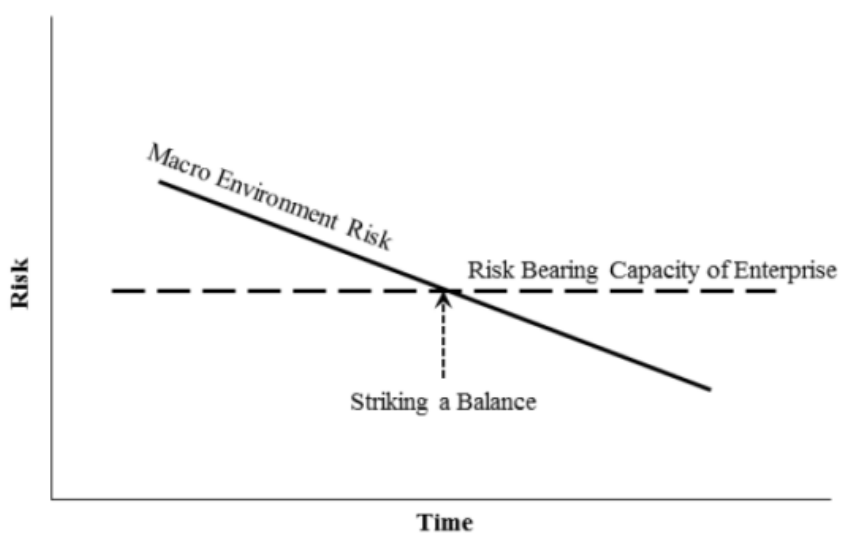

Source: Rasheed et al. (2018)

Changes in the macro-environment that are not in line with the company's strategy will lead to an increase in risk value and a reduction in the company's endurance due to the swelling operational costs and reduced operating income, which in the end if not properly anticipated will cause the company to stop operating.

The change in Rabobank's strategy in focusing more on the food and agriculture sector made this not in line with market conditions in Indonesia which tended to retail business, thus causing this business strategy to be very difficult to implement. The continued weakening of Rabobank's financial performance, since the customer's focus on this sector, has been carried out has made the company's operating expenses increase, which in turn has recorded a large loss, due to the 
imbalance between operating income and operating expenses. These results are consistent with Novak and Sajter (2007) Which states, the majority of bankrupt companies show very strategic flaws which are reflected in four business components and market positions. First, $81 \%$ of the total turnover is done only for one field of business. Secondly, $60 \%$ of the company is active only in one field of business. Third, $45 \%$ of the examined cases are the market leaders in their core business. Last almost the whole company is a follower in one field of business.

Indonesia, as a maritime country with more than 17 thousand islands, makes fisheries, sea, and air transportation businesses one of the sectors that have the potential to grow. The foresight of the company is looking at business potential, and business opportunities that are adjusted to the state of nature and the economic situation of a country is very vital. Because the characteristics of each country are different, so they cannot be equated. However, in the global context, if you look at the Rabobank group's very good and stable in terms of financial performance, choosing to focus on this sector (food and agriculture) is the right decision that has been chosen. With the value of $\mathrm{A}+$ as a branch of investment feasibility by Standard \& Poor's and the Aa3 value by Moody's Investors service making shares of this company very worthy of being collected. 
Figure 3. Operational Costs and Operating Income

\begin{tabular}{|c|c|}
\hline Bank operational costs & Bank operating income \\
\hline 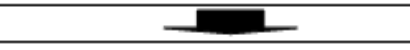 & 12 \\
\hline - Asset purchase and maintenance & - Loan interest \\
\hline - Payment of bank interest & - Administrative costs \\
\hline - Marketing costs & - Positive Exchange Rate Difference \\
\hline - Employee salary & - Sales of bank products \\
\hline - Payment of taxes & - Sales of bank services \\
\hline - And others & - And others \\
\hline ב & 2 \\
\hline Bank preferences & Consumer preferences \\
\hline
\end{tabular}

If the Operating Income is smaller than the operational costs

Then the Bank is required to change the focus of the strategy to adapt to business needs and environmental changes

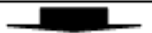

If not, the bank will continue to incur losses which in turn will stop operating

Figure three is an illustration of the flow of the relationship between operating expenses and operating income, where each component is interrelated with one another. Correct company management occurs when operating income is greater than operating expenses. The anticipation of changes in consumer preferences is an absolute must to be followed so that the company's needs from the operational side under consumer needs in terms of revenue. 
Figure 4. Risk Assessment Cycle

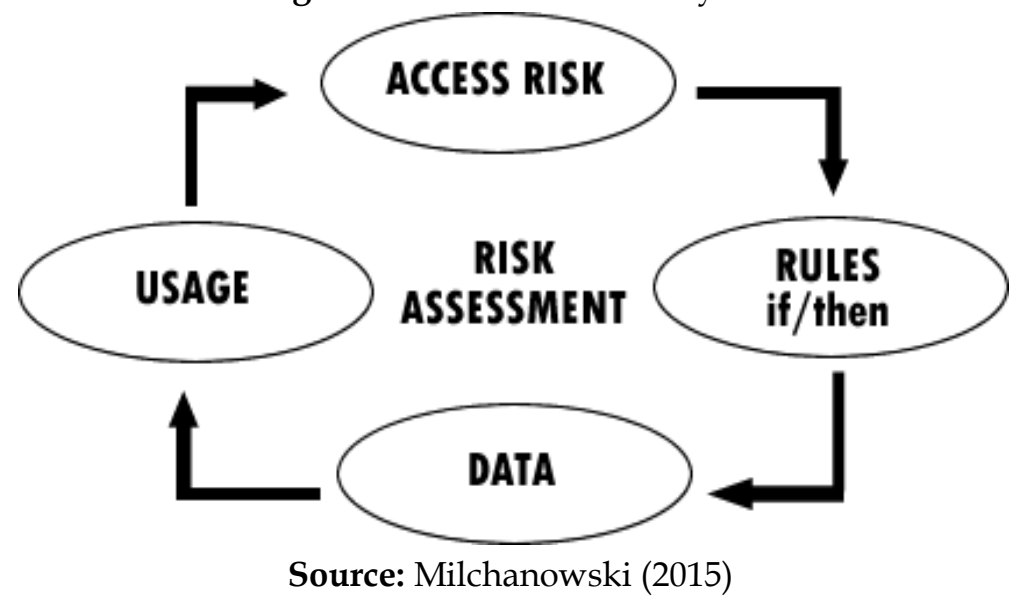

When related to risk measurement using figure four, the company position description is as follows. First, in the part of the data collected by Rabobank management (according to the author), there is a mistake in analyzing the data set of prospective bank customers that will be the initial target, they try to equalize the target customers with other regions, assuming that specialization or focus on certain customers becomes power certain attraction. Second, the misuse of data (possibly deliberate) shown by Rabobank has created a problem that has not been resolved in the last ten years, where they continue to strive to achieve the target customer's focus (special customers) by not seeing that the method is no longer in line with the dynamic changes in customers in Indonesia. Third, risk evaluation from the specialization efforts of the Rabobank central management makes the food and agribusiness sector the main source and the sole focus of the target prospective customers so that they are very difficult to get new customers every year, bearing in mind there are various characteristics of the occupation in Indonesia that do not only rely on in the food and agribusiness sector only. Fourth, the rules agreed upon by each branch in each country to refer to the company's vision and mission, making this decision continue to be made despite 
the differences in the characteristics of customers in each country. This seems (in the author's opinion) this is deliberately done considering the financial condition of the company center (Rabobank Group), which manages very stable and in a position to continue to increase every year both in terms of assets and overall net profit of the company.

\section{APPENDIX}

Table 2. Balance sheet (in a million rupiahs)

\begin{tabular}{|c|c|c|c|c|c|}
\hline & 2018 & 2017 & 2016 & 2015 & 2014 \\
\hline Total assets & $13,816,214$ & $11,888,583$ & $13,085,847$ & $15,292,213$ & $16,082,686$ \\
\hline Total loans & $10,989,427$ & $8,331,229$ & $9,396,179$ & $11,694,101$ & $11,712,944$ \\
\hline $\begin{array}{l}\text { Allowance } \\
\text { for impair- } \\
\text { ment losses }\end{array}$ & $(446,964)$ & $(109,878)$ & $(281,012)$ & $(868,114)$ & $(180,468)$ \\
\hline Total equity & $1,102,616$ & $1,802,467$ & $1,787,357$ & $1,518,767$ & $1,431,491$ \\
\hline Customer deposits & $7,851,938$ & $7,960,878$ & $10,184,608$ & $11,338,414$ & $13,240,078$ \\
\hline $\begin{array}{l}\text { Subordinated } \\
\text { loans }\end{array}$ & 776,520 & 451,119 & 589,422 & 637,556 & 603,769 \\
\hline
\end{tabular}

Source: Rabobank Indonesia's Annual Financial Report

Table 3. Statement of Profit or Loss and Other Comprehensive Income (in a million rupiahs)

\begin{tabular}{l|ccccc}
\hline & $\mathbf{2 0 1 8}$ & $\mathbf{2 0 1 7}$ & $\mathbf{2 0 1 6}$ & $\mathbf{2 0 1 5}$ & $\mathbf{2 0 1 4}$ \\
\hline Interest income & 910,162 & 895,663 & $1,259,601$ & $1,401,563$ & $1,367,372$ \\
Interest expense & $(474,122)$ & $(415,567)$ & $(686,364)$ & $(765,656)$ & $(737,182)$ \\
Otehr operating income & 92,194 & 123,964 & 149,541 & 50,751 & 55,652 \\
Other operating expense & $(807,673)$ & $(557,299)$ & $(587,997)$ & $(751,148)$ & $(586,681)$ \\
$\begin{array}{l}\text { Provision for } \\
\text { impairement losses on } \\
\text { financial assets }\end{array}$ & $(456,586)$ & $(27,064)$ & $(80,494)$ & $(746,026)$ & $(37,159)$ \\
Income from operations & $(736,025)$ & 19,697 & 54,287 & $(810,516)$ & 62,002 \\
$\begin{array}{l}\text { Non-operating } \\
\text { income/expense - net }\end{array}$ & 40,333 & 14,494 & 264,570 & $(21,203)$ & $(20,049)$ \\
Income tax expenses - net & $(8,547)$ & $(32,686)$ & $(58,450)$ & 114,688 & $(18,673)$ \\
Income/loss for the year & $(704,239)$ & 1,505 & 260,407 & $(71,031)$ & 23,280 \\
\hline
\end{tabular}

Source: Rabobank Indonesia's Annual Financial Report 
Tabel 4. Financial ratios (in a million rupiahs)

\begin{tabular}{l|ccccc}
\hline & $\mathbf{2 0 1 8}$ & $\mathbf{2 0 1 7}$ & $\mathbf{2 0 1 6}$ & $\mathbf{2 0 1 5}$ & $\mathbf{2 0 1 4}$ \\
\hline Capital Adequacy Ratio (CAR) & $15,19 \%$ & $22,06 \%$ & $20,05 \%$ & $13,27 \%$ & $15,06 \%$ \\
Non Performing Loans (NPL) - Gross & $5,82 \%$ & $2,45 \%$ & $4,46 \%$ & $8,41 \%$ & $3,54 \%$ \\
Non Performing Loans (NPL) - Net & $2,54 \%$ & $1,46 \%$ & $2,21 \%$ & $1,21 \%$ & $2,23 \%$ \\
Return on Assets (ROA) & $(5,30 \%)$ & $0,30 \%$ & $2,13 \%$ & $(5,09 \%)$ & $0,28 \%$ \\
Return on Equity (ROE) & $(44,69 \%)$ & $0,09 \%$ & $17,51 \%(56,23 \%)$ & $1,76 \%$ \\
Net Interest Margin (NIM) & $2,73 \%$ & $3,58 \%$ & $3,54 \%$ & $3,57 \%$ & $3,43 \%$ \\
Loan to Deposit Ratio (LDR) & $139,96 \%$ & $104,65 \%$ & $92,26 \%$ & $103,14 \%$ & $88,51 \%$ \\
\hline
\end{tabular}

Source: Rabobank Indonesia's Annual Financial Report 


\section{REFERENCE}

Akbar, C. 2019. Eksklusif: Bos Rabobank Blak-Blakan Soal Isu Tutup Di Indonesia [Online]. Available: Https://Bisnis.Tempo.Co/ Read/1201504/Eksklusif-Bos-Rabobank-Blak-Blakan-SoalIsu-Tutup-Di-Indonesia/Full\&View $=\mathrm{Ok}$ [Accessed 2 July 2019].

Apostolik, R., Donohue, C. \& Went, P. 2009. Operational Risk. Foundations Of Banking Risk: An Overview Of Banking, Banking Risks, And Risk-Based Banking Regulation. Johnwiley \& Sons, Inc.

Azis, A. \& Hartono, U. 2017. Pengaruh Good Corporate Governance, Struktur Modal, Dan Leverage Terhadap Kinerja Keuangan Perusahaan Pada Sektor Pertambangan Yang Terdaftar Di Bursa Efek Indonesia Tahun 2011-2015. Jurnal Lmu Manajemen, 5, 1-13.

Bouheni, F. B., Ammi, C. \& Levy, A. 2016. Banking Risk Analysis. Banking Governance, Performance And Risk-Taking: Conventional Banks Vs Islamic Banks. Iste Ltd And John Wiley \& Sons, Inc.

Darsono \& Ashari 2005. Pedoman Praktis Memahami Laporan Keuangan, Yogyakarta, Cv Andi Offset.

Fahmi, I. 2010. Manajemen Risiko - Teori, Kasus Dan Solusi, Bandung, Alfabeta.

Febriati, E. C. 2013. Analisis Penerapan Psak 55 Atas Cadangan Kerugian Penurunan Nilai. Jurnal Emba, 1, 207-217.

Ghosh, A. 2012a. Operational Risk Management. Managing Risks In Commercial And Retail Banking. John Wiley \& Sons Singapore Pte. Ltd.

Ghosh, A. 2012b. Risk Management Approaches And Systems. Managing Risks In Commercial And Retail Banking. Singapore: John Wiley \& Sons Singapore Pte. Ltd.

Girling, P. 2013. Definition And Drivers Of Operational Risk. Operational Risk Management: A Complete Guide To A Successful Operational Risk Framework. John Wiley \& Sons, Inc. 
Huertas, T. 2016. Too Important To Ignore: How Banks Can Get A Grip On Operational Risk [Online]. Ey Emeia Financial Services Risk Management Group. Available: Https://Www.Ey.Com /Publication/Vwluassets/Ey-Euromoney-Operational-RiskArticle_-June-2016/\$File/Ey-

Euromoney\%20operational\%20risk\%20article.Pdf [Accessed August 11 2019].

Lesmana, R. \& Surjanto 2004. Financial Performance Analyzing, Jakarta, Pt Gramedia.

Lukason, O. \& Hoffman, R. C. 2014. Firm Bankruptcy Probability And Causes: An Integrated Study. International Journal of Business And Management, 9.

Milchanowski, K. 2015. What Is The Model Risk In A Risk Assessment? [Online]. Usa: Acams. Available: Https://Www.Acamstoday.Org/What-Is-The-Model-RiskIn-A-Risk-Assessment/ [Accessed October 8 2019].

Novak, B. \& Sajter, D. 2007. Causes Of Bankruptcy In Europe And Croatia [Online]. Mpra Paper. Available: Https://Mpra.Ub.Uni-

Muenchen.De/5833/1/Mpra_Paper_5833.Pdf [Accessed August 12 2019].

Rasheed, S., Yaqub, F., Wang, C. F., Memon, S. \& Lucena, B. R. D. D. 2018. Risk Leveling - An Organised Risk Management Approach. Int. J. Risk Assessment And Management, 21, 135153.

Siahaan, H. 2009. Manajemen Risiko Pada Perusahaan Dan Birokrasi, Jakarta, Pt Gramedia.

Ufo, A. 2015. Determinants Of Financial Distress In Manufacturing Firms Of Ethiopia. Research Journal of Finance And Accounting, 6, 9-17.

Vysya, V. N. \& Gill, N. 2018. Operational Risk Management In Bank: The Way Forward [Online]. India: Infosys Limited Bengaluru. Available:Https://Www.Infosys.Com/Industries/Financial -Services/White-Papers/Documents/Risk-ManagementBanking.Pdf [Accessed August 13 2019]. 
Zedda, S. 2017. Banking Risk. Banking Systems Simulation: Theory, Practice, And Application Of Modeling Shocks, Losses, And Contagion. John Wiley \& Sons, Inc. 